Materiales de Construcción

Vol. 60, 299, 133-143

julio-septiembre 2010

ISSN: 0465-2746

eISSN: $1988-3226$

doi: $10.3989 / \mathrm{mc} .2010 .50809$

\title{
Nuevos materiales absorbentes acústicos basados en fibra de kenaf
}

\author{
New absorbent material acoustic based on kenaf's fibre
}

\author{
J. Ramis(*), J. Alba(**), R. del Rey(**), E. Escuder ${ }^{(* *)}$, V. J. Sanchís ${ }^{(* * *)}$
}

Recepción/Received: 18-II-2009

Aceptación/Accepted: 24-III-2009

Publicado online/Online publishing: 11-VIII-2010

\section{RESUMEN}

El carácter marcadamente prestacional de las normativas acústicas en la edificación abre el camino a la propuesta, por parte de empresas y particulares, de nuevos materiales acústicos susceptibles de ser utilizados en el ámbito de la acústica de la edificación. Éste es el caso que nos ocupa en el presente trabajo en el que se presenta un nuevo material acústico absorbente basado en fibras vegetales, concretamente el kenaf. Además se propone un modelo empírico de modelización del comportamiento absorbente de varias composiciones de este material en función de la frecuencia. Existen modelos de diferentes lanas minerales, lanas de roca, lanas de vidrio, espumas o lanas de poliéster. Algunos de estos modelos - llamados empíricos- se obtienen a partir del ajuste de ecuaciones de comportamiento de la impedancia acústica y la constante de propagación del material, en función de la resistencia al flujo, diámetro de las fibras, densidad, etc. Existen normativas como la UNE-EN 12354-6 que aceptan bajo ciertas limitaciones estos modelos como base en la predicción del comportamiento acústico de los materiales. A partir de los diferentes ensayos realizados en laboratorio, se proponen las ecuaciones empíricas de comportamiento acústico de este nuevo material. Además, se ha realizado un primer acercamiento a validar este modelo combinándolo con un modelo micro-estructural, basándonos en los pasos seguidos por Bies-Hansen (1), que nos permita obtener el valor de la resistencia al flujo.

Palabras clave: absorción acústica, impedancia acústi$\mathrm{ca}$, resistencia al flujo, fibras naturales.

\section{SUMMARY}

Acoustic Standards in the building are responsible for, companies and individuals, propose new acoustic materials for the sound isolation. This paper presents a new sound-absorbent material, it is based on natural fibres, particularly fibres of kenaf. It also proposes an empirical model for this material, this models depends on the frequency. There are accepted models from the scientific community about mineral wool, glass wool, rock wool, foam or polyester fibre. Several of these models are empirical. They are obtained from the equation adjustments about the acoustic impedance and propagation constant behaviour, depending upon the flow resistivity, fibre's diameter and density. There are even standards like UNE-EN 12354-6 where these models are accepted under certain limitations like the fundamental basis as in the materials' acoustics behaviour prediction. From the various tests conducted in the laboratory, empirical equations are proposed for this new acoustic material. In addition, there has been a first approach to validate this model in combination with a micro-structural model, based on the steps taken by Bies-Hansen (1), which allows us to obtain the value of the resistance to flow.

Keywords: sound absorption, acoustic impedance, airflow resistivity, natural fibre.

(*) Universidad de Alicante (Alicante, España).

(**) Escuela Politécnica Superior de Gandía. Universidad Politécnica de Valencia (Valencia, España).

(***) PIEL S.A. Agullent (Valencia, España). 


\section{INTRODUCCIÓN}

En nuestras casas, el problema de ruido se ha visto incrementado gracias a la proliferación de nuevos electrodomésticos, nuevas tecnologías y nuevas costumbres. Es sabido desde hace años, que para reducir el ruido dentro de las viviendas pueden utilizarse materiales absorbentes, algunos de ellos no reciclables fácilmente o cuyo contacto con los seres humanos no es recomendable. Sin embargo, el aumento del precio del petróleo, la problemática de reutilización de residuos de muchas industrias e incluso el consumo masivo de ciertas materias primas por mercados emergentes, hace que haya que cuestionarse nuevos tipos de materiales, reciclados de residuos de sistemas industriales o basados en fibras naturales (2). Una alternativa pueden ser las fibras basadas en plantas y la elaboración de materiales absorbentes acústicos a partir de éstas.

Como es sabido, la mayor parte de los problemas acústicos en el ámbito del acondicionamiento, tales como ecos, focalizaciones, excesiva reverberación, etc., tienen como única solución la aplicación de materiales absorbentes. Estos materiales absorbentes, se aplican, asimismo, en el ámbito del aislamiento acústico, formando parte de particiones multicapa atenuando el efecto de las ondas estacionarias entre placas. El carácter prestacional de la gran mayoría de las normativas acústicas en la edificación ha provocado una creciente oferta de materiales acústicos. Este hecho ha traído consigo la necesidad de afrontar la implementación de modelos que hicieran más fácil la predicción del comportamiento de estos materiales formando parte de un dispositivo para una aplicación de acondicionamiento o aislamiento acústico. Los modelos más básicos intentan abordar el comportamiento frecuencial de los materiales, utilizando como base dos variables conocidas como impedancia característica y constante de propagación, que sirven para predecir el comportamiento de propagación y absorción en el seno de estos materiales, entre otras cosas.

A lo largo de los últimos años, han ido apareciendo diferentes modelos empíricos basados en ajustes de medidas de materiales a ecuaciones lineales $u$ otras. Los materiales más estudiados en este sentido han sido la lana de roca y la lana de vidrio. Uno de los modelos más conocidos y utilizados en esta línea es el de Delany-Bazley (3). Conviene, asimismo, citar los trabajos posteriores de Miki (4-5), que mejoran el propuesto por (3), los modelos para espumas como el de DunaDavern (6) o para fibras textiles como el de Garai-Pompoli (7). Existen otros trabajos empíricos como el de Wang et al. (8), basado en una regresión a diferentes variables, o el de Shoshani y Yakubov (9) para la búsqueda de la máxima absorción. No hay que

\section{INTRODUCTION}

The problem with the noise at home has been increased due to the growing proliferation of domestic electrical appliances, new technologies and new habits. As it is generally known, to reduce the noise inside the buildings absorbing materials can be used, some of which are not easily-recyclable or which are not recommendable for humans to be in contact with. However, the petroleum price rise, the problematic with industries reusing residues and even the massive consumption of some raw materials by emerging markets make us think of new kinds of materials, recycled from industrial systems residues or based on natural fibres. An alternative can be fibres based on plants and the manufacture of acoustic absorbing materials from these.

Most of the acoustic problems in terms of fitting out such as echoes, focalisations, excessive reverberations, etc., find their solution by only applying absorbing materials. Moreover, these absorbing materials are applied in acoustic isolation by being part of the multi-layer partitions to attenuate the standing waves effects between the plates. The performance based nature of most of the acoustic standards in construction has caused a growing offer on acoustic materials. This has also implied the necessity to face the implementation of models which could make the prediction of the interaction of these materials easier, being then part of a device for a fitting out or an acoustic isolation. The most basic models try to focus on the frequencies interaction of the materials, using as a basis two variables known as characteristic impedance and constant of propagation, which are used to predict the interaction of propagation and absorption inside these materials, among others. In the latter years they have appeared different empirical models based on measurement adjustments of materials to linear equations or others.

The most studied materials in this sense have been stone wool and glass wool. One of the best known and used models here is the Delany-Bazley (3). It is also recommendable to mention further works by Miki (4-5), which improve the one proposed by Delany-Bazley (3), the models for foams such as Dunn- \& Davern's one (6) or for textile fibres such as Garai- \& Pompoli's (7). There are other empirical works such as Wang et al (8), based on a regression to different variables, or the one by Shoshani and Yakubov (9) for the search for the maximum absorption. We must not forget about the different empirical models proposed by Voronina (1013), in which there are the parameters such as tortuosity or structure factor associated to the fibres or pores 
olvidar tampoco los diferentes modelos empíricos propuestos por Voronina (10-13), en los que aparecen parámetros como la tortuosidad o factor de estructura, asociados a la distribución de las fibras o poros que caracterizan estos materiales. En este contexto además, normativas, como la UNE-EN 12354:2003 "Estimación de las características acústicas de las edificaciones a partir de las características de sus elementos", y en concreto la parte 6 , "Absorción sonora en espacios cerrados" (14), aconsejan el uso de fórmulas para la predicción de la absorción de materiales absorbentes. En el caso de materiales compuestos por fibras, Delany-Bazley (3) es la referencia obligada, y en el caso de materiales porosos, Duna-Davern (6) es el modelo elegido por la norma.

En este trabajo se presenta un modelo semi-empírico desarrollado tomando como referencia los pasos seguidos por Garai-Pompoli (7). En el citado trabajo, se realiza un ajuste para determinar los coeficientes que mejor describían el comportamiento acústico de las fibras de poliéster. En el caso que nos ocupa, se ha implementado un método para obtener los coeficientes para el caso de materiales absorbentes obtenidos a partir de fibras naturales, concretamente, el kenaf.

Para la propuesta que se formula se han utilizado fibras naturales que verifican las prestaciones de materiales ya consolidados en el mercado y que al mismo tiempo presentan ciertas ventajas adicionales que pueden consultarse en (15). En la Figura 1 se presentan dos imágenes de microscopio de muestras de kenaf. Como se puede apreciar, se trata de un material poroso y fibroso. Por tanto, dada su naturaleza, es de esperar que desempeñe un papel similar a otros materiales porosos y fibrosos como la lana de roca. Estos materiales se obtienen utilizando la fibra de poliéster en porcentaje conocido como elemento de termo fusión para unir las fibras de kenaf, consiguiendo un material compuesto en su mayoría por fibra de kenaf y sin el uso de adhesivos para conformarlo. layout which characterize these materials. Moreover, in this context, standards such as UNE-EN 12354:2003: 'Constructions acoustic characteristics estimation from the characteristics of its elements' and specifically in part 6, 'Sound absorption indoors' (14), advice the use of formulas for the prediction of the absorption of absorbing materials. In case of materials made up of fibers Delany-Bazley (3) are the compulsory reference and, when they are porous materials Dunn-Davern (6) are the model used by the standard.

In this project it is introduced a semi-empirical model developed following Garai-Pompoli (7). In that project there is an adjustment to determine the coefficients that best describe the acoustic interaction of the polyester fibres. In our project, it has been implemented a method to get the coefficients for the absorbing materials obtained from natural fibres, specifically, the Kenaf method.

For our proposal, they have been used natural fibres that verify the features of materials already established in the market which also present certain additional advantages that can be checked in (15). In Figure 1 we present two microscope images of samples of kenaf. As it can be observed, It is a porous and fibrous material. Thus, according to its nature, the role is expected to be similar to other porous and fibrous materials such as stone wool. These materials are obtained by using polyester fibre in a percentage known as thermo fusion element to join the kenaf fibres, getting a material mostly made up from kenaf fibre and without the use of adhesive to make it.

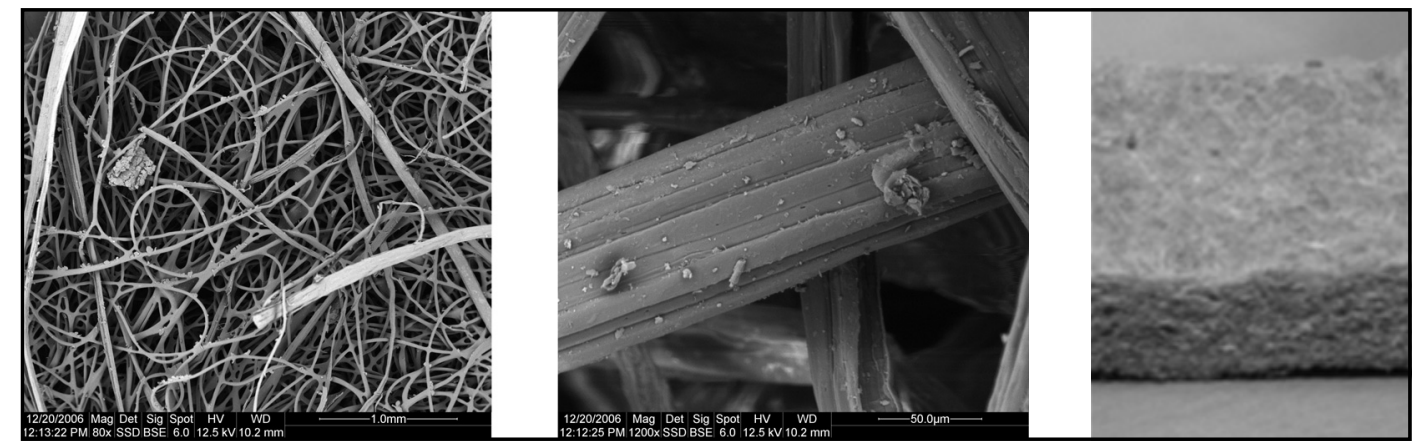

Figura 1. Imágenes a diferente escala de las fibras naturales de kenaf. Figure 1. Images at different scales of natural fibers of kenaf. 


\section{FUNDAMENTOS}

El modelo semi-empírico que presentamos en este trabajo pretende describir el comportamiento acústico del material fibroso utilizando el menor número posible de parámetros físicos no intrínsecos, atenuando de esta forma algunos errores de propagación que se cometen al utilizar parámetros obtenidos experimentalmente para implementar modelos empíricos.

Básicamente, se trata de encontrar los coeficientes $\mathrm{Ci}$ $(i=1 \ldots 8)$ que mejor ajusten las siguientes ecuaciones para el caso del material que estamos tratando:

\section{BASICS}

The semi-empirical model presented in this project is to describe the acoustic behaviour of fibrous materials, according to a few no intrinsic physical parameters. Thus we have in the equation the smallest possible margin of error.

Basically, it comes to finding the coefficients $\mathrm{Ci}$ ( $i=1 \ldots 8$ ) that best fit the following equations for the case of material we are dealing with:

$$
\begin{gathered}
\alpha=\left(\frac{2 \times \pi \times f}{C_{0}}\right) \times\left[C_{5} \times\left(\frac{\rho_{0} \times f}{r}\right)^{-C_{6}}\right] \\
\beta=\left(\frac{2 \times \pi \times f}{C_{0}}\right) \times\left[1+C_{7} \times\left(\frac{\rho_{0} \times f}{r}\right)^{-C_{8}}\right] \\
Z_{R}=\rho_{0} \times C_{0}\left[1+C_{1} \times\left(\frac{\rho_{0} \times f}{r}\right)^{-C_{2}}\right] \\
Z_{1}=-\rho_{0} \times C_{0}\left[C_{3} \times\left(\frac{\rho_{0} \times f}{r}\right)^{-C_{4}}\right]
\end{gathered}
$$

Donde $\alpha$ y $\beta$ son la parte real e imaginaria de la constante de propagación del material, $Z_{R}$ y $Z_{I}$ son la parte real e imaginaria de la impedancia característica normalizada y $\mathrm{r}$ la resistencia al flujo en $\left(\mathrm{N} \mathrm{x} \mathrm{s} / \mathrm{m}^{4}\right), \rho_{0}$ es la densidad del aire $\left(\approx 1,2 \mathrm{~kg} / \mathrm{m}^{3}\right)$, f la frecuencia $(\mathrm{Hz})$ y $\mathrm{c}_{0}$ es la velocidad del sonido en el aire $(\approx 343 \mathrm{~m} / \mathrm{s})$.

Además, para obtener el coeficiente de absorción a partir de la constante de propagación y la impedancia descrita en [1] utilizamos la siguiente expresión:
Where $\alpha$ and $\beta$ are the real $Z_{R}$ and $Z_{I}$ imaginary parts of the propagation constant, $r$ and are there real and imaginary parts of the specific acoustic impedance, is the airflow resistivity $\left(\mathrm{N} x \mathrm{~s} / \mathrm{m}^{4}\right), f$ is the frequency $(\mathrm{Hz})$, $\rho_{0}$ is the air density $\left(\approx 1.2 \mathrm{~kg} / \mathrm{m}^{3}\right)$ and $c_{0}$ is the sound velocity in the air $(\approx 343 \mathrm{~m} / \mathrm{s})$.

Moreover, to obtain the sound absorption coefficient through the propagation constant and the specific acoustic impedance [1] using the expression:

$$
\alpha_{n}=\frac{4 \cdot Z_{1} \cdot \rho_{0} \cdot c_{0}}{\left|Z_{1}\right|+2 \cdot \rho_{0} \cdot c_{0} \cdot Z_{1}+\left(\rho_{0} \cdot c_{0}\right)^{2}}
$$

Siendo I el espesor de la muestra y la expresión para la impedancia de cierre:
Being I the thickness of the sample and the expression for the closing impedance:

$$
Z_{I}=\left(Z_{R}+j \times Z_{1}\right) \times[\operatorname{coth}(\alpha+j \times \beta) \times I]
$$

\subsection{Descripción del modelo semi-empírico}

Para llevar a cabo el ajuste, es necesario, disponer de datos del coeficiente de absorción para incidencia normal

\section{1. description of the semi-empirical model}

In order to carry out with the adjustment it is necessary to have the absorption coefficient data for normal 
y de resistencia al flujo del material en cuestión. Los datos de entrada básicos son los de la resistencia al flujo, ya que nos permiten obtener la parte real e imaginaria de la constante de propagación del material, así como la parte real e imaginaria de la impedancia característica normalizada.

Para obtener el coeficiente de absorción para incidencia normal, se ha aplicado el método de la función de transferencia [ISO10534] (16). El procedimiento seguido se describe de forma detallada en (17). En la Figura 2 se presenta un esquema del dispositivo experimental con las posiciones de los micrófonos y la muestra. Las señales recogidas por los dos micrófonos, previo tratamiento descrito en la normativa, permiten determinar el coeficiente de absorción. El diámetro del tubo limita la frecuencia superior de medida. La característica del método hace además que la distancia entre los micrófonos marque un límite en frecuencia.

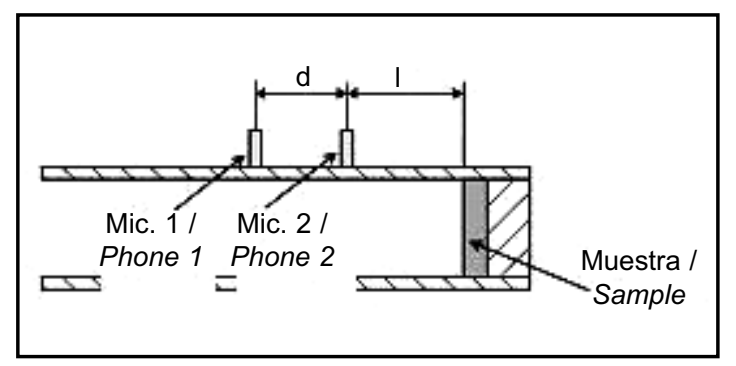

Figura 2. Dispositivo experimental para la medida del coeficiente de absorción para incidencia normal [ISO10534]. Figure 2. Experimental device for measuring the absorption coefficient for normal incidente [ISO 10534].

La resistencia al flujo del material, se ha determinado experimentalmente en laboratorio utilizando el método de Ingard-Dear (18), que constituye una alternativa ventajosa a la Norma UNE-EN 29053:1994 (19). De una forma breve, la muestra a caracterizar se coloca en un tubo como el que se muestra en la Figura 3. Debe verificarse $\lambda>>1,7$ $D$, donde $D$ es el diámetro del tubo y $\lambda$ la longitud de onda considerada. Si L es la distancia entre la muestra de material y la terminación rígida, debe cumplirse: incidence and the resistance to flow of the material. The basic input data are those of the resistance to flow since they allow us to get the real and imaginary part of the propagation constant of the material as well as the real and imaginary part of the standardized characteristic impedance.

So as to obtain the absorption coefficient for normal incidence it has been applied the transfer function method [ISO10534] (16). The process is described in detail in (17). Figure 2 presents an outline of the experimental dispositive with the positions of the microphones and the sample. The signals collected with the microphones, prior treatment described in the standard, let determine the absorption coefficient. The diameter of the tube limits the higher frequency of the measurement. The characteristic of the method also makes the distance between the microphones to set a limit in frequency.

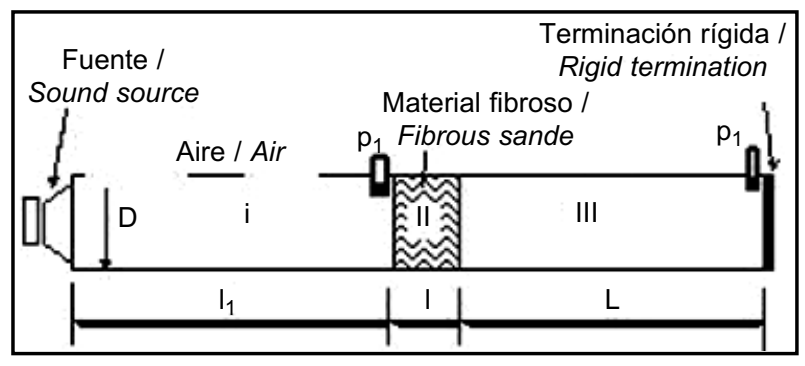

Figura 3. Método de Ingard-Dear para la determinación de la resistencia al flujo.

Figure 3. Dear-Ingard method for determining the flow resistivity.

The resistance to flow of the material has been determined in the laboratory by using the Ingard\&-Dear Method (18), which is a favourable alternative to the Standard UNE-EN 29053:1994 (19). In short, the sample to characterize is placed in a tube like the one shown in Figure 2. It must be verified $\lambda>>1.7 D$, where $D$ is the diameter of the tube and $\lambda$ the wave length. If $L$ is the distance between the sample of the material and the rigid termination, must be fulfilled:

$$
\mathrm{L}=\frac{(2 \mathrm{n}-1) \lambda}{4} \mathrm{n}=1,2, \ldots
$$

La resistencia al flujo puede obtenerse a partir de la función de transferencia de las señales de los dos micrófonos, ya que para ciertas frecuencias la parte reactiva de la impedancia se anula. Midiendo el nivel de presión sonora para estas frecuencias en los puntos p1 y p2, como se muestra en la Figura 3, el valor de la resistencia específica al flujo, $r$ viene dada por:
The resistance to flow can be obtained from the transfer function of the two microphones signals, since for some frequencies the reactive part of the impedance is cancelled. By measuring the sound pressure level for these frequencies in the points $p 1$ and $p 2$, as shown in Figure 3, the value of the resistance to flow, $r$, is to be:

$$
r=\frac{\rho_{\mathrm{O}} C_{\mathrm{O}}}{\mathrm{I}} 10^{\frac{L p 1-L p 2}{20}}
$$


Donde $\rho_{\mathrm{o}}$ es la densidad del aire, $c_{0}$ es la velocidad de propagación del sonido y Lp1 y Lp2 son los niveles de presión sonora medidos en los puntos 1 y 2 , respectivamente.

Para obtener los coeficientes que describen de mejor forma el comportamiento acústico medido de las muestras de material de kenaf, hemos utilizado un método iterativo de disminución de función de error cuadrática. Como valores iniciales, valores de entrada, hemos probado diferentes valores propuestos por diferentes autores, todos los valores convergen a los coeficientes que hemos obtenido y que se presentan en este trabajo. La función de error cuadrática del método iterativo utilizado, se define de la siguiente forma:
Where $\rho_{o}$ is the air density, $c_{o}$ is the sound propagation speed and Lp1 y Lp2 are the levels of sound pressure measured in points 1 and 2.

In order to obtain the coefficients that best fit the measured acoustic interaction of the kenaf samples we have used an iterative method of decrease of squared error function. As the initial values, input values, we have tried different values proposed by different authors. All values converge to the coefficients we have obtained and which are shown in this project.

The squared error function of the iterative method used is defined as follows:

$$
\varepsilon=\sum_{i=1}^{N}\left(\alpha_{n, i}-\hat{\alpha}_{n, i}\right)^{2}
$$

donde $\alpha_{n, i}$ representa el valor del coeficiente de absorción en incidencia normal, medido para un material absorbente elegido, a la frecuencia i-ésima y $\hat{\alpha}_{n, i}$ es la estimación del valor anterior realizada a partir de las ecuaciones [1] a [4]. Para la minimización de la función de error es necesario igualar a cero la siguiente expresión: where $\alpha_{n, i}$ represents the absorption coefficient for normal incidence value, measured for a chosen absorbing material, at $i$-th frequency and $\hat{\alpha}_{n, i}$ is the estimation of the previous value got from the equations [1] to [4]. For the error function minimization it is necessary to equal to zero a cero the following expression:

$$
\frac{\partial \varepsilon}{\partial A}=2 \sum_{i=1}^{N}\left(\alpha_{n, i}-\hat{\alpha}_{n, i}\right) \frac{\partial \hat{\alpha}_{n, i}}{\partial A_{i}}=0 \quad i=1, \ldots, 8
$$

\section{RESULTADOS}

\subsection{Coeficientes semi-empíricos}

En la Tabla 1 se enumeran algunas de las muestras de kenaf estudiadas y algunas de sus características básicas. Los espesores, densidades y resistencia al flujo del

\section{RESULTS}

\subsection{Semi-empirical coefficients}

Table 1 lists some of the kenaf samples analysed and also some of their basic characteristics. The thicknesses, densities and resistances to flow of the rest of the

Tabla 1 / Table 1

Valores de espesor, densidad y resistencia al flujo de algunas de las muestras ensayadas. Thickness, density and flow resistance values of some of the samples tested.

\begin{tabular}{|c|c|c|c|}
\hline Nombre / Name & $\begin{array}{c}\text { Espesor }(\mathbf{m m}) / \\
\text { Nominal thickness }(\mathbf{m m})\end{array}$ & $\begin{array}{c}\text { Densidad }\left(\mathbf{k g} / \mathbf{m}^{\mathbf{3}}\right) / \\
\text { Bulk density }\left(\mathbf{k g} / \mathbf{m}^{3}\right)\end{array}$ & $\begin{array}{c}\text { Resistencia al flujo }\left(\mathbf{P a} \mathbf{s} / \mathbf{m}^{2}\right) / \\
\text { Airflow resistivity }\left(\mathbf{P a} \mathbf{s} / \mathbf{m}^{2}\right)\end{array}$ \\
\hline $\mathrm{k} 15$ & 44 & 47 & 17649 \\
\hline $\mathrm{k} 12$ & 42 & 60 & 5226 \\
\hline $\mathrm{k} 14$ & 82 & 62 & 6628 \\
\hline $\mathrm{k} 9$ & 68 & 65 & 2059 \\
\hline $\mathrm{k} 3$ & 28 & 70 & 5712 \\
\hline $\mathrm{k} 13$ & 73 & 70 & 5662 \\
\hline $\mathrm{k} 6$ & 15 & 73 & 4045 \\
\hline $\mathrm{k} 2$ & 18 & 79 & 4710 \\
\hline $\mathrm{k} 4$ & 22 & 86 & 6167 \\
\hline $\mathrm{k} 1$ & 19 & 120 & 4798 \\
\hline $\mathrm{k} 8$ & 18 & 125 & 30000 \\
\hline
\end{tabular}


resto de las muestras estudiadas se encuentran dentro de los márgenes de los valores en esta tabla presentados.

En la Tabla 2 se observa el valor de los coeficientes propuestos por los diferentes autores. Se presentan los proporcionados por Delany-Bazley (3), éstos fueron obtenidos basando el estudio en lana de roca (diámetro medio de fibra de $10 \mu \mathrm{m}$ ), los proporcionados por Garai-Pompoli (7) basándose en fibras de poliéster (diámetro medio de fibra de $36 \mu \mathrm{m}$ ), y los valores obtenidos en el estudio del kenaf. Es destacable cómo estos absorbentes presentan en su mayoría, más de 5 $\mathrm{kPa} . \mathrm{s} / \mathrm{m}^{2}$. samples analysed are within the margins of the values shown in this table.

Table 2 shows the values of the coefficients proposed by the different authors. They are presented those by Delany-Bazley (3), which were obtained focusing the study on the analysis of the rock wool (average fibre diameter of $10 \mu \mathrm{m})$. Then, the proposed by GaraiPompoli (7) based on polyester fibres (average fibre diameter of $36 \mu \mathrm{m}$ ) and, the values obtained with the kenaf. It is remarkable how most of these absorbents show, more than $5 \mathrm{kPa} . \mathrm{s} / \mathrm{m}^{2}$.

Tabla 2 / Table 2

Valores de los ocho coeficientes que se han obtenido para el kenaf, comparados con los valores obtenidos por Delany-Bazley y Pompoli-Garai.

Values of the eight coefficients were obtained for kenaf compared with values obtained by Delany and Delany-Bazley and Pompoli-Garai.

\begin{tabular}{|c|c|c|c|c|c|c|c|c|}
\hline Modelo / Model & C1 & C2 & C3 & C4 & C5 & C6 & C7 & C8 \\
\hline Delany & 0.057 & 0.754 & 0.087 & 0.732 & 0.189 & 0.595 & 0.098 & 0.700 \\
\hline Pompoli & 0.078 & 0.623 & 0.074 & 0.660 & 0.159 & 0.571 & 0.121 & 0.530 \\
\hline Propuesta Kenaf / Kenaf & 0.046 & 0.255 & 0.112 & 0.967 & 0.060 & 1.256 & 0.039 & 0.541 \\
\hline
\end{tabular}

En la Tabla 3 se observa la desviación media cometida entre el valor medido del coeficiente de absorción en incidencia normal y los valores calculados, utilizando los coeficientes propuestos por Delany-Bazley (3), PompoliGarai (7), y utilizando el modelo, en este trabajo descrito, el modelo para el kenaf.
Table 3 shows the mean deviation between the measured values of the sound absorption coefficient and the calculated values using Delany-Bazley method (3), Pompoli-Garai method (7) and kenaf method.

Tabla 3 / Table 3

Desviación media entre los valores medidos del coeficiente de absorción en incidencia normal y los predichos por diferentes modelos.

Mean deviation between the measured values of the sound absorption coefficient and the predicted by different models.

\begin{tabular}{|c|c|}
\hline Modelo / Model & $\begin{array}{c}\text { Desviación (\%) entre los valores medidos y los predichos } \\
\text { por diferentes autores I } \\
\text { Deviation (\%) between the measured values and predicted values } \\
\text { by others authors }\end{array}$ \\
\hline Delany-Bazley & 9.87 \\
\hline Pompoli-Garai & 9.07 \\
\hline Kenaf & 5.63 \\
\hline
\end{tabular}

En las Figuras 4, 5, 6 y 7 podemos observar valores del coeficiente de absorción medido y valores predichos utilizando diferentes modelos y el modelo aquí expuesto. Las Figuras 4 y 5 muestran estos resultados para muestras de kenaf de $70 \mathrm{~kg} / \mathrm{m}^{3}, 73$ y $28 \mathrm{~mm}$, respectivamente. En la Figura 6 la muestra de kenaf es de $60 \mathrm{~kg} / \mathrm{m}^{3}$ y $42 \mathrm{~mm}$ y en la Figura 7 de $65 \mathrm{~kg} / \mathrm{m}^{3}$ y $68 \mathrm{~mm}$.
In Figures 4, 5, 6 and 7 we can observe the values of the sound absorption coefficient measured and predicted values using different models and the model here shown. Figures 4 and 5 show the results for the kenaf samples of $70 \mathrm{~kg} / \mathrm{m}^{3}, 73$ and $28 \mathrm{~mm}$, respectively. In Figure 6 the kenaf sample is of $60 \mathrm{~kg} / \mathrm{m}^{3}$ and $42 \mathrm{~mm}$ and in figure 7 it's of $65 \mathrm{~kg} / \mathrm{m}^{3}$ and $68 \mathrm{~mm}$. 


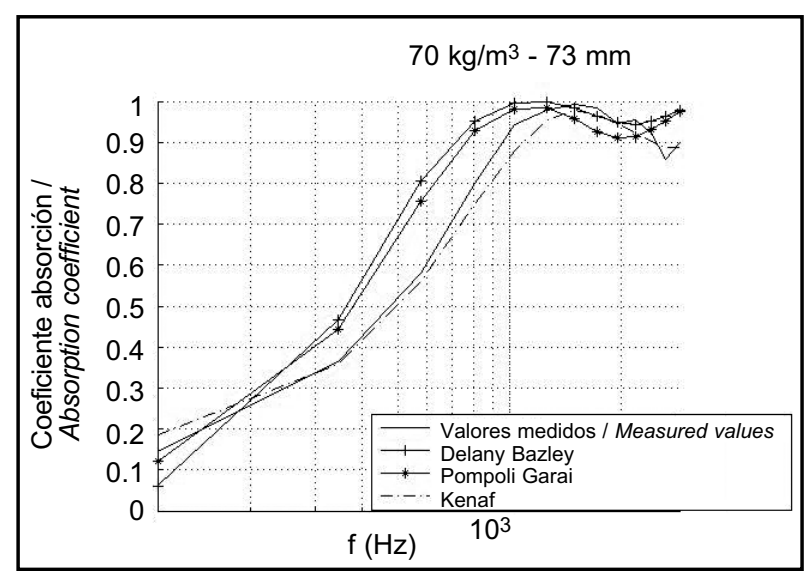

Figura 4. Coeficiente de absorción en incidencia normal; comparación entre valores medidos y predichos por diferentes modelos.

Figure 4. Absorption coefficient in normal incidence, comparison between measured and predicted values by different models.

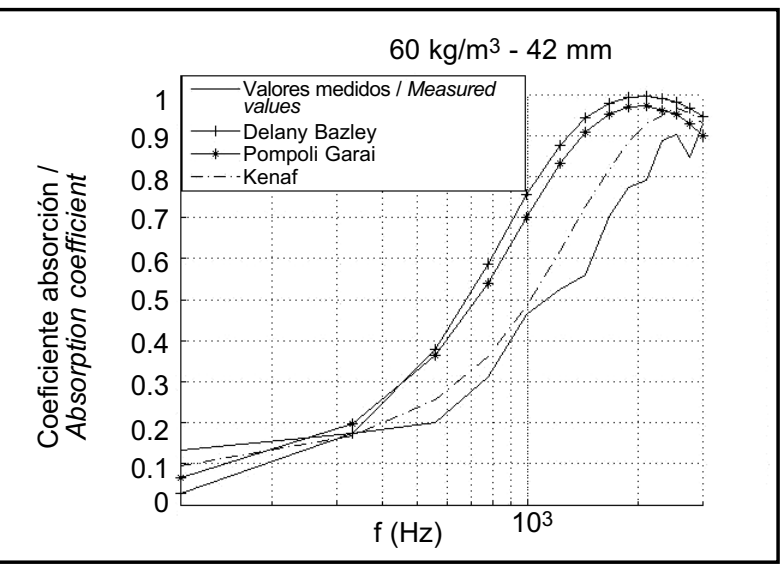

Figura 6. Coeficiente de absorción en incidencia normal; comparación entre valores medidos y valores predichos por diferentes modelos.

Figure 6. Absorption coefficient in normal incidence, comparison between measured and predicted values by different models.

\subsection{Pre-diagnóstico del modelo micro-estructural}

Con el objeto de realizar una validación complementaria se ha procedido a combinar los resultados obtenidos aplicando un modelo micro-estructural, tomando como referencia los pasos seguidos por Bies-Hansen (1), que nos permite obtener el valor de la resistencia al flujo. Dicho de otra forma, se ha realizado un pre-diagnóstico del modelo estructural para las muestras de kenaf estudiadas basándonos en el modelo de Bies-Hansen (1). Este modelo permite obtener la resistencia al flujo a partir de la densidad del material, $\rho_{\mathrm{m}}$ y del diámetro medio de las fibras que lo componen, $d$.

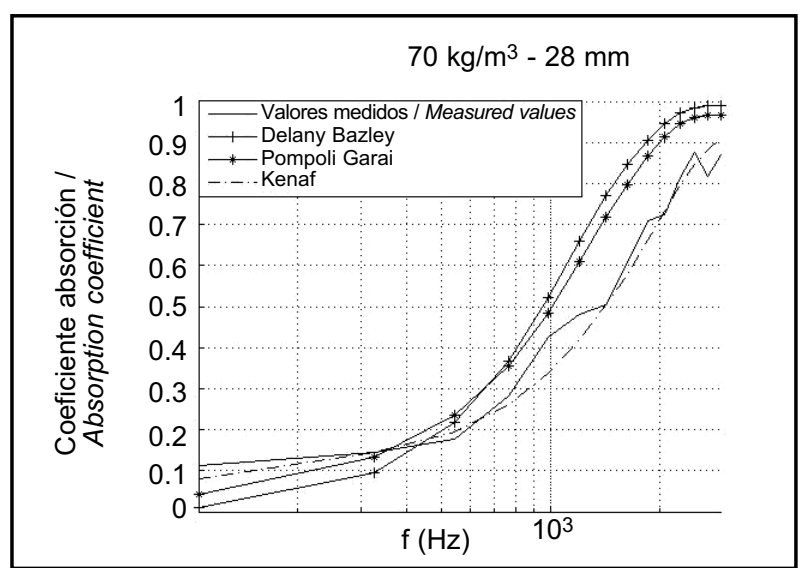

Figura 5. Coeficiente de absorción en incidencia normal; comparación entre valores medidos y valores predichos por diferentes modelos.

Figure 5. Absorption coefficient in normal incidence, comparison between measured and predicted values by different models.

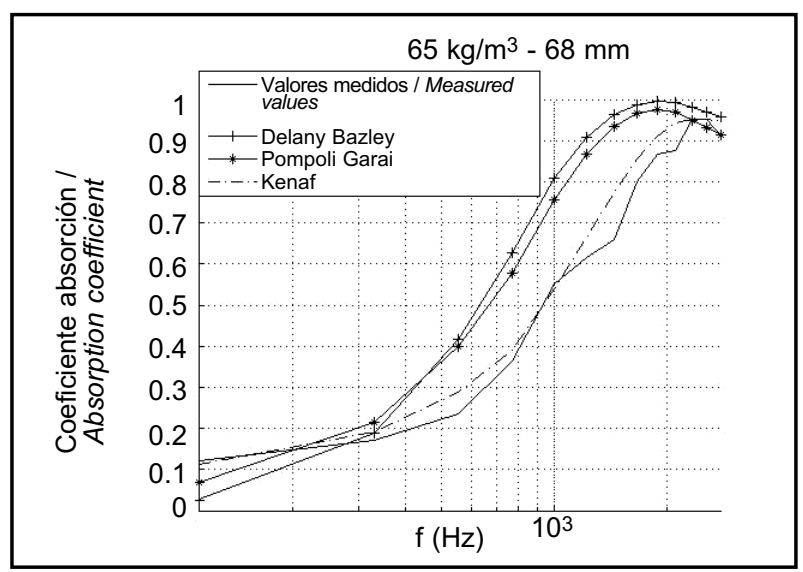

Figura 7. Coeficiente de absorción en incidencia normal; comparación entre valores medidos y valores predichos por diferentes modelos.

Figure 7. Absorption coefficient in normal incidence, comparison between measured and predicted values by different models.

\subsection{Pre-diagnósis of microestructural model}

In order to carry out a complementary validation we have proceed to combine the obtained results applying a micro-structural model, taking as a reference BiesHansen (1), which allows us to obtain the value of resistance to flow. In other words, a pre-diagnosis of the structural model has been done for the kenaf samples analysed focusing on the Bies\&Hansen model (1). This model let us obtain the resistance to flow from the density of the material, $\rho_{m}$, and of the average diameter of the fibres which make it, $d$.

$$
r=\frac{K_{2} \times \rho_{m}{ }^{k_{1}}}{d^{2}}
$$


Este modelo proporciona buenos resultados para la lana de roca, para la que los valores de $k_{1}$ y $k_{2}$ son, respectivamente, 1,53 y $3,18 \cdot 10^{-9}$. Pompoli-Garai (7) estudiaron este mismo modelo para la fibra de poliéster no obteniendo resultados satisfactorios, por lo que pensaron que, debido a la diferencia entre los valores de los diámetros medios $(1-10 \mu \mathrm{m})$ para la lana de roca y $36 \mu \mathrm{m}$ para la fibra de poliéster, era necesario encontrar nuevos valores de $k_{1}$ y $k_{2}$. La expresión anterior se puede reescribir en la forma:

$$
r=K_{3} \times \rho_{m}^{k_{1}}
$$

Donde $k_{3}=k_{2} / d^{2}$

Where $k_{3}=k_{2} / d^{2}$

Tomando logaritmos neperianos.

Taking neperian logarithms.

$$
\ln r=\ln k_{3}+k \ln \rho_{m}
$$

Por tanto, podemos obtener k1 y k3 para el material estudiado, compuesto básicamente de fibras de kenaf. En la Tabla 4 se pueden observar los valores obtenidos de k1 y k3 para este material, comparado con el de otros autores. El coeficiente de correlación obtenido, $\mathrm{R}^{2}$, es de 0,9817, para el margen de densidades de la Tabla 1.

Tabla 1.
This model provides good results for rock wool, so as the values $k_{1}$ and $k_{2}$ are 1.53 and 3.18.10-9. Pompoli-Garai (7) studied this model for the polyester fibre without satisfactory results and so they thought that due to the difference between the values of the average diameter (1-10 $\mu \mathrm{m})$ for rock wool and $36 \mu \mathrm{m}$ for polyester fibre, new values of $k_{1}$ and $k_{2}$ were needed. The previuous expression can be rewritten as follows:

Tabla 4 / Table 4

Valores de los parámetros K1 y k3 obtenidos por Bies-Hansen (lanas minerales), Pompoli-Garai (fibras de poliéster) y para el Kenaf.

Values of the parameters $K 1$ and $k 3$ obtained by Bies-Hansen (mineral wool), Pompoli-Garai (polyester fiber) and Kenaf.

\begin{tabular}{|c|c|c|}
\hline & K1 & K3 \\
\hline Bies-Hansen & 1.53 & 2.92 \\
\hline Pompoli-Garai & 1.40 & 25.98 \\
\hline Kenaf & 1.90 & 1.86 \\
\hline
\end{tabular}

\section{CONCLUSIONES}

En primer lugar se puede observar cómo estos nuevos materiales presentan las características de un material absorbente acústico poroso: esto se observa en el coeficiente de absorción obtenido y en el valor de la resistencia al flujo. Además, desde el punto de vista de la fabricación, se ha conseguido un material estable, que mediante la termofusión de fibras de poliéster se consigue un material compuesto en su mayoría de fibras de kenaf.

Por otro lado, desde el punto de vista teórico, la correlación entre los valores medidos en laboratorio y valores predichos, utilizando el modelo frecuencial (constante de
Thus, we can obtain $k 1$ and $k 3$ for the material studied, basically made up of kenaf fibres. Table 4 shows the values obtained of $k 1$ and $k 3$ for this material, compared to other authors'. The correlation coefficient obtained, $R^{2}$, is of 0.9817 , for the margin of densities of Table 1 .

\section{CONCLUSIONS}

First of all, it can be seen how these new materials have the characteristics of a porous acoustic absorbing material. This is checked in the absorption coefficient obtained and in the value of the resistance to flow. Moreover, from the manufacture point of view, it has been achieved a stable material which by thermo fusion of polyester fibres it is obtained a material mostly made up of kenaf fibres.

On the other hand, from the theoretical point of view, the correlation between the values measured in the laboratory and the predicted ones, using the frequencies 
propagación e impedancia acústica), con los coeficientes obtenidos en este trabajo es satisfactoria. El modelo de Delany-Bazley (3) se ajusta a los valores experimentales en algunos materiales, como lana de roca. El modelo de Pompoli-Garai (7) también se ajusta de forma satisfactoria a los valores experimentales para las fibras de poliéster. Se ha desarrollado un modelo, modelo kenaf, que se ajusta a los valores experimentales para este bio-material fibroso. Además se ha realizado un primer acercamiento a validar este modelo combinándolo con un modelo micro-estructural, basándonos en los pasos seguidos por Bies-Hansen (1), que nos permita obtener el valor de la resistencia al flujo.

En futuros trabajos sobre este bio-material, se analizarán más muestras con el fin de intentar ajustar aún más las predicciones a los valores experimentales.

\section{AGRADECIMIENTOS}

Este trabajo ha sido financiado por el Ministerio de Educación y Ciencia. DG Research (BIA2007-C02-01 y BIA2007-C02-02). model (propagation constant and acoustic impedance), with the coefficients obtained in this project is satisfactory. The Delany-Bazley model (3) complies with the experimental values in some materials, such as rock wool. The Pompoli-Garai model (7) also complies satisfactorily the experimental values for the polyester fibres. It has been developed a model, the kenaf model, which complies the experimental values for this fibrous bio-material. Furthermore, a first step towards validation of this model has been made, combining it with a microstructural model, focusing on Bies-Hansen (1), to allow us to obtain the value of the resistance to flow.

In future projects about this bio-material, more samples will be analysed so as to try to comply the predictions about the experimental values much more.

\section{ACKNOWLEDGEMENTS}

This project has been funded by the Ministry of Education and Science. DG Research (BIA2007-C02-01 y BIA2007-C02-02).

\section{BIBLIOGRAFÍA / BIBLIOGRAPHY}

(1) Bies, D. A.; Hansen, C. H: "Flow resistance information for acoustical desing". Applied Acoustics (1980), vol. 13, pp. 357-391. doi:10.1016/0003-682X(80)90002-X

(2) http://www.fao.org/index_es.htm

(3) Delany, M. E.; Bazley, E. N.: "Acoustical Properties of Fibrous Absorbent Materials". Applied Acoustics, no 3 (1970), pp. 105116. doi:10.1016/0003-682X(70)90031-9

(4) Miki, Y.: "Acoustical Properties of Porous Materials-Modifications of Delany-Bazley Models". Journal of the Acoustical Society Jpn (E), no 11, 1 (1990) pp. 19-24.

(5) Miki, Y.: "Acoustical Properties of Porous Materials-Generalitations of empirical models". Journal of the Acoustical Society Jpn (E), no 11, 1 (1990) pp. 13-24.

(6) Dunn, I. P.; Davern, W. A.: "Calculation of acoustic impedance of multi-layer absorbers". Applied Acoustics, n 19 (1986), pp. 321-334. doi:10.1016/0003-682X(86)90044-7

(7) Garai, M.; Pompoli, F.: "A simple empirical model of polyester fibre materials for acoustical applications". Applied Acoustics, no 66 (2005), pp. 1383-1398. doi:10.1016/j.apacoust.2005.04.008

(8) Wang, X. et al.: "Regression analysis of acoustical properties of polyurethane foams". Journal of Sound and Vibration, n० 273 (2004), pp. 1109-1117. doi:10.1016/j.jsv.2003.09.039

(9) Shoshani, Y.; Yakubov, Y.: "Numerical assessment of maximal absorption coefficients for nonwoven fiberwebs". Applied Acoustics, no 59 (2000), pp. 77-87. doi:10.1016/S0003-682X(99)00015-8

(10) Voronina, N.: "Improved Empirical Model of Sound Propagation Through a Fibrous Material". Applied Acoustics, vol. 48, no 2 (1996), pp. 121-132. doi:10.1016/0003-682X(95)00055-E

(11) Voronina, N.: "An Empirical Model for Elastic Porous Materials". Applied Acoustics, vol. 55, no 1 (1998), pp. 67-83. doi:10.1016/S0003-682X(97)00098-4

(12) Voronina, N.: "An empirical model for rigid-frame porous materials with low porosity". Applied Acoustics, no 58 (1999) pp. 295304. doi:10.1016/S0003-682X(98)00076-0

(13) Voronina, N.; Horoshenkov, K. V.: "A new empirical model for the acoustic properties of loose granular media". Applied Acoustics, no 64 (2003), pp. 415-432. doi:10.1016/S0003-682X(02)00105-6

(14) UNE-EN 12354-6:2004: Acústica en la edificación. Estimación de las características de las edificaciones a partir de las características de sus elementos, parte 6 , Absorción sonora en espacios cerrados. 
(15) Del Rey, R.; Alba, J.; Sanchís, V.: "Proposal a empirical model for absorbent acoustical materials based in kenaf". 19th International Congress on Acoustics. Madrid, 2-7 septiembre de 2007.

(16) UNE-EN ISO 10534-2: Acústica: "Determinación del coeficiente de absorción acústica y de la impedancia acústica en tubos de impedancia", parte 2, "Método de la función de transferencia" (ISO 10534-2:1998).

(17) Navacerrada, M. A.; Díaz, C.; Pedrero, A.; García, L. E.: "Absorción acústica de espumas de aluminio". Mater. Construcc., vol. 58, no 291 (2008).

(18) Ingard, K. U.; Dear, T. A.: "Measurement of Acoustic Flow Resistance". Journal of sound and Vibration, no 103 (1985), pp. 567-

572. doi:10.1016/S0022-460X(85)80024-9

(19) UNE-EN 29053:1994. Acústica. Materiales para aplicaciones acústicas. Determinación de la resistencia al flujo de aire. (ISO9053:1991) 